\title{
Seasonal evolution of the nutrient pattern on Biscay Bay continental shelf over the years 1999-2000*
}

\author{
SOPHIE LOYER ${ }^{1}$, LUIS LAMPERT $^{2}$, ALAIN MENESGUEN $^{3}$, PHILIPPE CANN $^{3}$ \\ and THIERRY LABASQUE ${ }^{4}$ \\ ${ }^{1}$ Atlantide, Technopôle Brest Iroise, site du Vernis - CS 23866, 29238 BREST Cedex 3, France. \\ E-mail address : sloyer@ago.fr \\ ${ }^{2}$ IFREMER, DEL/PB, Port-en-Bessin, France. \\ ${ }^{3}$ IFREMER, DEL/ EC, Plouzané, France. \\ ${ }^{4}$ EPSHOM, CMO, Brest, France.
}

\begin{abstract}
SUMMARY: The French Atlantic shelf is subjected to strong anthropic influences (urban, industrial and agricultural discharges) of two main rivers (Loire and Gironde). The extension and consequences of these continental loadings for the nutrient and chlorophyll distribution have never been studied before on the Bay of Biscay continental shelf as a whole. We present the first synoptic view of the nutrient distribution and evolution on the French Atlantic shelf. Nutrient concentrations of the surface layer were studied during four cruises in April, June, September 1999 and March 2000. Until June, the freshwater inputs induce a nitrate gradient from river mouths to offshore waters in the vicinity of the $100 \mathrm{~m}$ isobath. The Redfield's ratio study highlights the nitrate excess in river loadings. The early spring situation is characterised by high $\mathrm{N}: \mathrm{P}$ ratios in front of the two estuaries and by a potential Si-limitation in the northern part. Nitrate removal continues in spite of the Plimitation and the increase in silicate concentrations during summer supposes high regeneration processes. At the end of summer, the water column is thermally stratified and the surface mixed layer is totally depleted in nitrate.
\end{abstract}

Keywords: Bay of Biscay, coastal water, river inputs, nutrients.

RESUMEN: EVOLUCIÓN ESTACIONAL DEL PATRÓN DE NUTRIENTES SOBRE LA PLATAFORMA CONTINENTAL DEL GOLFO DE VIZCAYA DURANTE LOS AÑOS 1999-2000. - La zona de plataforma del Atlántico francés está sujeta a una fuerte influencia antropogénica (urbana, industrial, descargas de la agricultura) principalmente de dos rios (Loire y Gironde). La extensión y consecuencias de tales descargas continentales sobre la distribución de nutrientes y clorofila, no ha sido todavía estudiada en la totalidad de la plataforma continental del golfo de Vizcaya. Aquí presentamos una visión sinóptica de la distribución y evolución de nutrientes sobre la plataforma del Atlántico francés. Las concentraciones de nutrientes de las capas superficiales han sido estudiadas durante 4 campañas en abril, junio, septiembre de 1999 y marzo de 2000. Hasta junio, los aportes de agua dulce inducen a un gradiente de nitratos desde la desembocadura del río hasta las aguas oceánicas en la vecindad de la isobata de $100 \mathrm{~m}$. La determinación del cociente de Redfield evidencia una descarga del río con exceso de nitrato. La situación de principios de primavera está caracterizada por un cociente alto de N:P en contraste con los dos estuarios y por una potencial limitación de Si en la parte norte. La eliminación de nitrato que tiene lugar, a pesar de la limitación de fósforo y el incremento de la concentración de Si durante el verano, supone procesos de alta regeneración. Al final del verano, la columna de agua está termicamente estratificada y la superficie de la capa de mezcla está totalmente agotada de nitrato.

Palabras clave: golfo de Vizcaya, agua costera, aportes de ríos, nutrientes.

\section{INTRODUCTION}

The Bay of Biscay is located in the north-eastern Atlantic. It can be seen as a large open bay with a

*Received March 17, 2003. Accepted July 1, 2005. large French continental shelf oriented NS and a narrow Spanish continental shelf oriented EW (Koutsikopoulos and Le Cann, 1996) (Fig. 1).

For twenty years or so, the marine ecosystem of the French Atlantic continental shelf has been subject to evaluation of its living resources (aquaculture 
and fisheries) which represent an important economic activity. Observation and monitoring of the quality of the coastal sea are part of the actions undertaken to protect the environment and to support sustainable development of fishing resources. In this context, physical dynamics and biotic interactions are essential aspects of this mission. Our study focuses on the coastal zone and attempts to provide the main characteristics of the chemical environment. The coastal zone plays a key role in the biological cycle of the species fished (spawn areas, nurseries, migration paths) and thus contributes to the productivity of resources. Nevertheless, the coastal ecosystems of the French Atlantic coast along its entire length are not yet fully known. These ecosystems are stressed by human activities and especially by nutrient discharges coming from agriculture, which could affect coastal primary production.

The Atlantic waters have a typical salinity of 35.5 (Boucher et al., 1985). This value is used to characterise oceanic waters. The French Atlantic shelf receives a significant input of freshwater from the two major rivers (Loire and Gironde) which are enriched with nitrogen, phosphate and silicate. Their annual outflow is about $900 \mathrm{~m}^{3} \mathrm{~s}^{-1}$ with spring and winter peaks often higher than $3000 \mathrm{~m}^{3} \mathrm{~s}^{-1}$. There is a weak NW residual circulation and the main currents are generated by tides (in the north part of the study area) and wind. The NW/SE winds generate the largest vertically integrated currents (Pingree and Le Cann, 1989). In the vicinity of estuaries, freshwater induces a density circulation. In the absence of strong wind forcing, river plumes spread towards the NW and remain confined along the coast (Lazure and Jegou, 1998).

During the last decades, concern about the impact of high nitrate freshwater input to the coastal zone has increased (Lancelot et al., 1987; Marchetti et al., 1988; Van der Veer et al., 1989; Radach et al., 1990; Reid et al., 1990; Joint and Pomroy, 1993; De Jonge et al., 1994; Biggs and Sanchez, 1997; Harding and Perry, 1997; Legovic and Justic, 1997). In the coastal ecosystem, intense primary production is primarily related to high nutrient loading originating from river discharges and eventually leading to eutrophication. These river flows have an impact on the stabilisation of the water column, on the content of suspended matter and on the nutrient discharges and their dilution. Therefore, they can enhance the primary production in coastal areas (Lancelot et al., 1987; Radach,
1991; Turner and Rabalais, 1991; De Jonge et al., 1994; Peperzak et al., 1996; Harding and Perry, 1997). In the same way, the physical regulation of phytoplankton blooms by haline stratification has already been shown in coastal waters (Morin et al., 1991; Malej et al., 1995; Yin et al., 1996).

The oceanic part of the Bay of Biscay has been studied many times. Koutsikopoulos and Le Cann (1996) focused on spatial and temporal scales of physical processes related to the life cycle of anchovy. Pingree and Le Cann (1989) have used a barotropic model to study the response to forcing of the different wind components. A numerical hydrodynamical study (Lazure and Jegou, 1998) showed that the influence of the Loire and Gironde river plumes can extend far from the estuary and is related to the meteorological conditions. The wind speed and density currents play an essential role in determining the position of river plumes. Compared to physical studies, there are few studies concerning the biological and chemical parameters of the French Atlantic shelf. The existing data were obtained near the shelf break (Treguer et al., 1979), in front of the Gironde estuary (Herbland et al., 1998; Labry et al., 2001), along the south Brittany coast (Morin et al., 1991) and in estuarine bays like Marennes Oleron basin (Delmas et al., 1990; Delmas et al., 1992) and the Bay of Vilaine (Maggi et al., 1986; Chapelle et al., 1994).

Belin et al. (1989) have noted an increasing trend of the toxic blooms along the French Atlantic coast. They assume a potential role of enrichment by river inputs. Nitrate fluxes in the Loire have remained stable over the last decades at a value of about 400000 $\mathrm{t}^{-1}$, but they can exceed $900000 \mathrm{t} \mathrm{y}^{-1}$ in exceptional years like in 1988 and 1994 (Sauriau et al., 1996). Phosphate fluxes range from 6000 to $10000 \mathrm{t} \mathrm{y}^{-1}$ with some peaks over $18000 \mathrm{t} \mathrm{y}^{-1}$ in 1988 and 1994 but they do not show any trend. For the Gironde River, nitrate concentrations seem to have increased by $25 \%$ over the last ten years, but phosphate concentrations remain unchanged (Maurice, 1993). Nitrate fluxes are lower than those of the Loire; their mean is about $200000 \mathrm{t} \mathrm{y}^{-1}$.

The objective of this study is to provide a better understanding of the Bay of Biscay ecosystem by giving a synoptic view of the nutrient distribution and evolution at the scale of the whole French Atlantic shelf, complementing the local studies.

Our data do not allow us to estimate nutrient flows. Rather, our objectives are to provide (1) a description of the phytoplankton and nutrient pools 

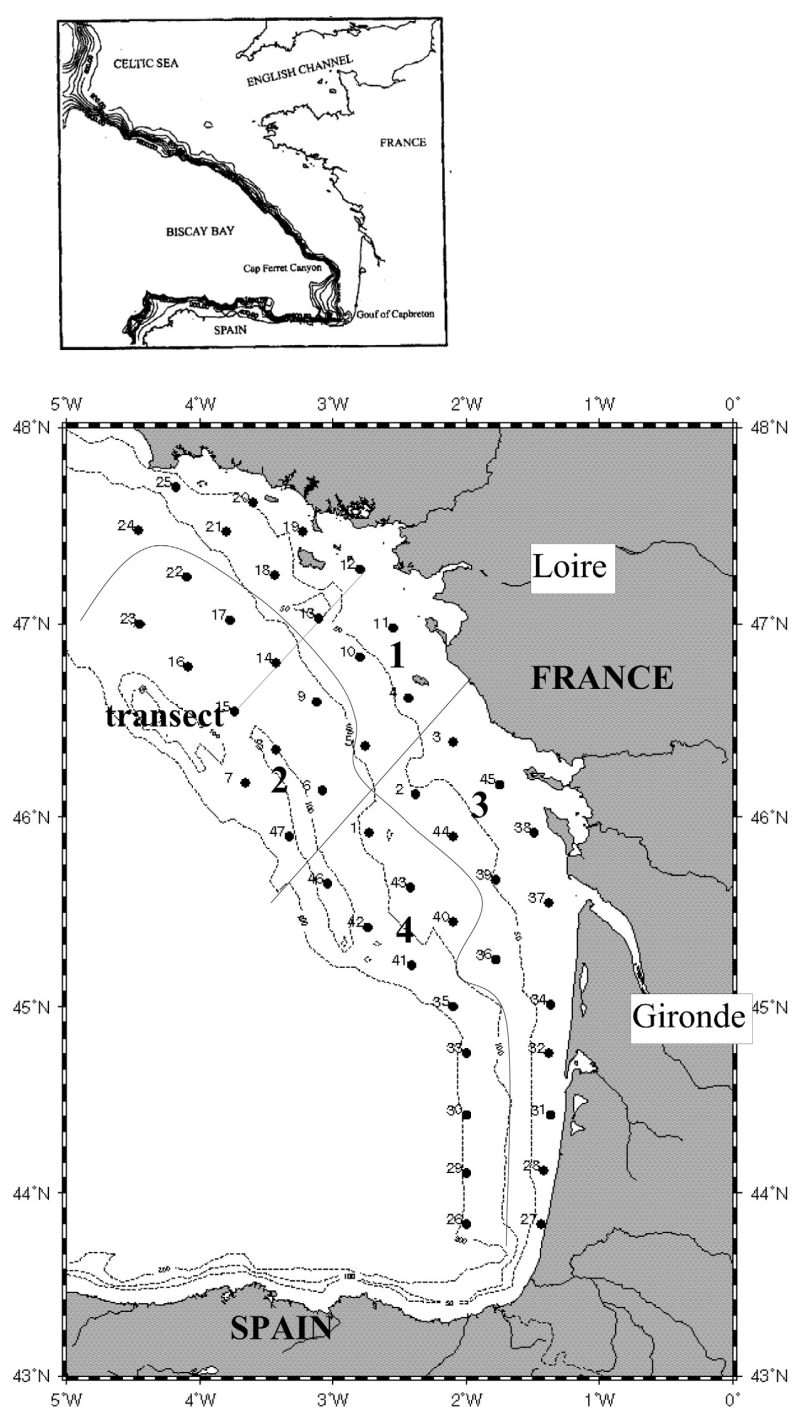

FIG. 1. - Location of sampling stations with the three isobaths $50 \mathrm{~m}$, $100 \mathrm{~m}$ and $200 \mathrm{~m}$. The transect perpendicular to the mouth of the Loire river represents the vertical section shown in Figure 5. This figure also represents the four areas chosen according to the EW and NS gradients.

distribution at different seasons and (2) a dataset to calibrate existing models of this area (Loyer et al., 2001; Lazure and Jegou, 1998). After the description of the seasonal evolution of nutrient patterns, this paper deals with the N:P:S ratios and explores which nutrients may potentially limit phytoplankton growth.

\section{MATERIALS ANDS METHODS}

\section{Sampling strategy}

Sampling was performed during the BioModycot cruises [Service Hydrographique et
Océanographique de la Marine (SHOM) and IFRE$M E R$ joint project] on board the BH2 Laperouse research vessel (SHOM). From April 1999 to March 2000, 50 stations located from near shore to offshore waters (depth of $150 \mathrm{~m}$ ) were visited four times (Fig. 1). The winter conditions are represented by the last cruise (00) which took place in March 2000 (from 28 February until 8 March). Two cruises took place in April (from 7 until 15 April) and June (from 8 until 15 June) $1999(99-1,99-2)$ in order to follow the variability during spring. The April cruise was preceded by a period of great winter instability (Fig. 2). In April, freshwater in river plumes was a major factor of stratification. A last cruise took place in September 1999 (from 7 until 14 September), at the end of summer (99-3). The Bio-Modycot datasets, with about $40 \mathrm{~km}$ between sampling points, are the first cruises with this spatial resolution in the French Atlantic shelf.

Vertical profiles of conductivity, temperature and depth (CTD Sea Bird 911+) were recorded at every station. In addition, $5 \mathrm{~L}$ water samples were taken at a depth of 5 meters for chemical and biological measurements. Vertical resolution was increased along a transect in front of the Loire estuary. Samples were taken at different depths in order to describe the vertical structure of the water column. Concentrations of major nutrients [nitrate+nitrite, phosphate and silicate] and chlorophyll $a$ were determined in the water samples.

\section{Analytical methods}

At each sample depth the salinity values measured by the CTD were calibrated according to the

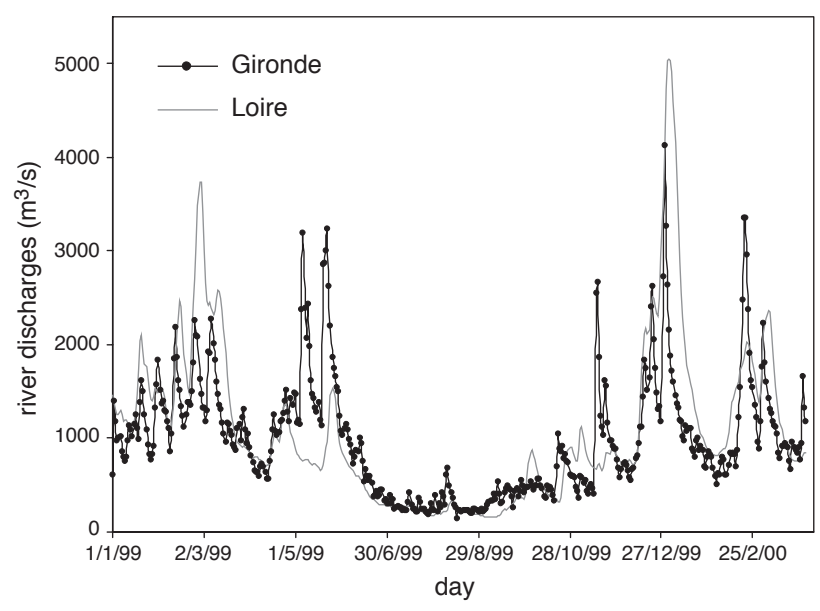

FIG. 2. - Daily average data curve of the two main freshwater discharges during the sampling period. 
measurements made using a Guildline Autosal 8400 salinometer (precision: \pm 0.001 ).

Nitrate + nitrite $( \pm 0.1 \mu \mathrm{M})$, phosphate $( \pm 0.01 \mu \mathrm{M})$ and silicate $( \pm 0.05 \mu \mathrm{M})$ concentrations were measured by a Technicon Auto Analyser II (precision $\pm 1 \%$ ), according to Treguer and Le Corre (1975).

For chlorophyll $a$ analysis, $1 \mathrm{~L}$ seawater samples were pre-filtered through $200 \mu \mathrm{m}$ mesh nylon gauze and then filtered onto $25 \mathrm{~mm}$ GF/F fibre filters under a low-pressure vacuum $(<0.5$ bar, following Del Amo et al. (1997). Filters were stored immediately at $-20^{\circ} \mathrm{C}$ on board for the duration of the cruise and were kept in the laboratory for a maximum of 7 months at $-80^{\circ} \mathrm{C}$. Chlorophyll $a$ was extracted and analysed following the reversephase HPLC method (High Performance Liquid Chromatography) slightly modified (Wright et al., 1991).

The contribution of each taxonomic group to the total chlorophyll $a$ stock was calculated using the CHEMTAX program (Mackey et al., 1996). The following taxonomic markers, alloxanthin (allo), 190butanoyloxyfucoxanthin (19BF), fucoxanthin (fuco), peridinin (peri), prasinoxanthin (prasi), zeaxanthin (zea), 190-hexanoyloxyfucoxanthin (19HF) and chlorophyll b (Chl b) are respectively, typical pigments of cryptophytes, chrysophytes (and pelagophytes), diatoms, photosynthetic dinoflagellates, prasinophytes, coccoid cyanobacteria, prymnesiophytes and "green algae" (Lampert, 2001). The phytoplankton size classes were approached by pigment markers and validated by microscopic counts in Lampert (2001) following the method of Vidussi (1998).

A multivariate analysis was carried out to synthesise the interpretation of the large set of data obtained during the three cruises. The ACP was carried out using the Data Analysis Module UNISTAT of the Statgraphics software. A spreadsheet of the whole area was established using the surface measures of the three cruises. Parameters taken into account were salinity, temperature, nitrate, silicic acid, phosphate and chlorophyll.

\section{RESULTS}

\section{Hydrological environment}

The seasonal changes of the hydrological structures have already been described (Lazure and Jegou, 1995; Koutsikopoulos and Le Cann, 1996;

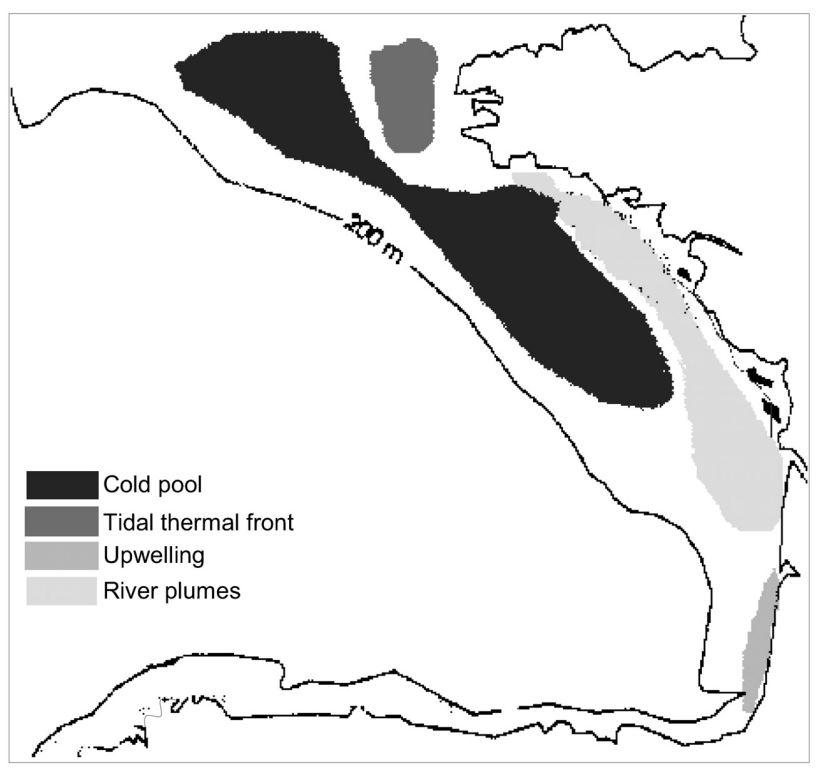

FIG. 3. - Synthetic graph with the main hydrological structures, according to Koutsikopoulos and Le Cann, 1996.

Puillat et al., 2004). The following synthetic graph represents the location of the main hydrological characteristics (Fig. 3). It summarises the main features found during these four cruises (for temperature and salinity maps, see Puillat et al., 2004).

In late winter (March 2000), the main hydrological features are characterised by river plumes. The river plumes induce a significant vertical salinity gradient in the first $50 \mathrm{~m}$. This gradient is associated with a thermal inversion with less-saline and cold waters in the surface layer. Salinity ranges from 32 to 35.8 and the temperature varies between $11.4^{\circ} \mathrm{C}$ and $11.6^{\circ} \mathrm{C}$. The isohaline 35.5 , which represents the limit of the plume waters' extension, reaches the $100 \mathrm{~m}$-isobath owing to the high winter runoffs. The surface temperature map shows a weak horizontal gradient with a cooler coastal band.

The spring and summer situations are represented by the cruises made in 1999 (in April and June). Heavy rainfalls in March 1999 resulted in high river flows. For the two main rivers, the Loire and Gironde, the maxima of daily river discharge reached $3000 \mathrm{~m}^{3} \cdot \mathrm{s}^{-1}$ and $1500 \mathrm{~m}^{3} \cdot \mathrm{s}^{-1}$ respectively. These river plumes induce an expansion of the 34.5 isohaline as far as the $100 \mathrm{~m}$ isobath. This spreading is also due to the northward current generated by the earth's rotation and known to favour the offshore advection of coastal waters towards the continental slope (Hermida et al., 1998; Lazure and Jegou, 1998). The offshore spreading of freshwater induces a strong vertical haline stratification in the first $30 \mathrm{~m}$ over most of the continental shelf. This stratification 
intensifies towards the coast. In April, a low thermal stratification is associated with this front. The increase in solar radiation and the decrease in high wind events favour temperatures rising.

In June, hydrological features show a shift from the winter haline stratification to the summer thermal stratification. The development of this thermocline isolates a structure called "bourrelet froid" (cold pool) by Vincent and Kurc (1969). This is a homogeneous cold water mass with inter-annual and seasonal fluctuations less than $1^{\circ} \mathrm{C}$ (Vincent, 1973). Its location in offshore waters ( $\geq 100 \mathrm{~m}$ deep) corresponds to the zone of weak tidal stirring. With the
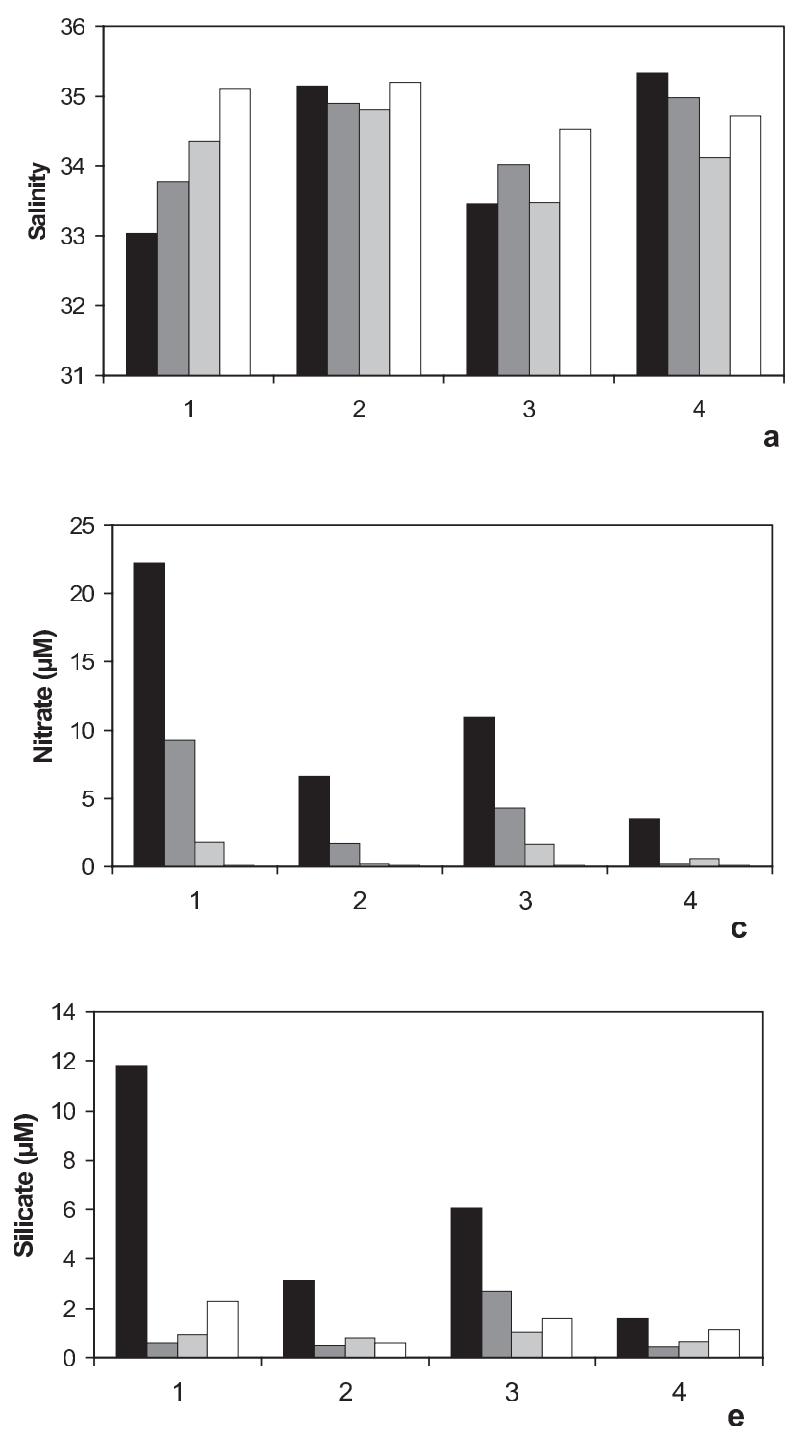

decrease in river flows, salinity tends to be uniform. The overall salinity range is 32.4 to 35.5 , with the less saline waters in front of the Gironde estuary. The corresponding temperature range is $13.8^{\circ} \mathrm{C}$ to $18.8^{\circ} \mathrm{C}$, with the coolest waters northward. A strong thermocline associated with the halocline is observed at 30 to $40 \mathrm{~m}$ depth.

The end of the summer is represented by the cruise in September (99-3). This survey displays higher surface temperatures than the two previous cruises. The overall temperature range is $19.8^{\circ} \mathrm{C}$ to $22.8^{\circ} \mathrm{C}$, compared with $13.8^{\circ} \mathrm{C}$ to $18.8^{\circ} \mathrm{C}$ in June and it shows a strong NS horizontal gradient. The
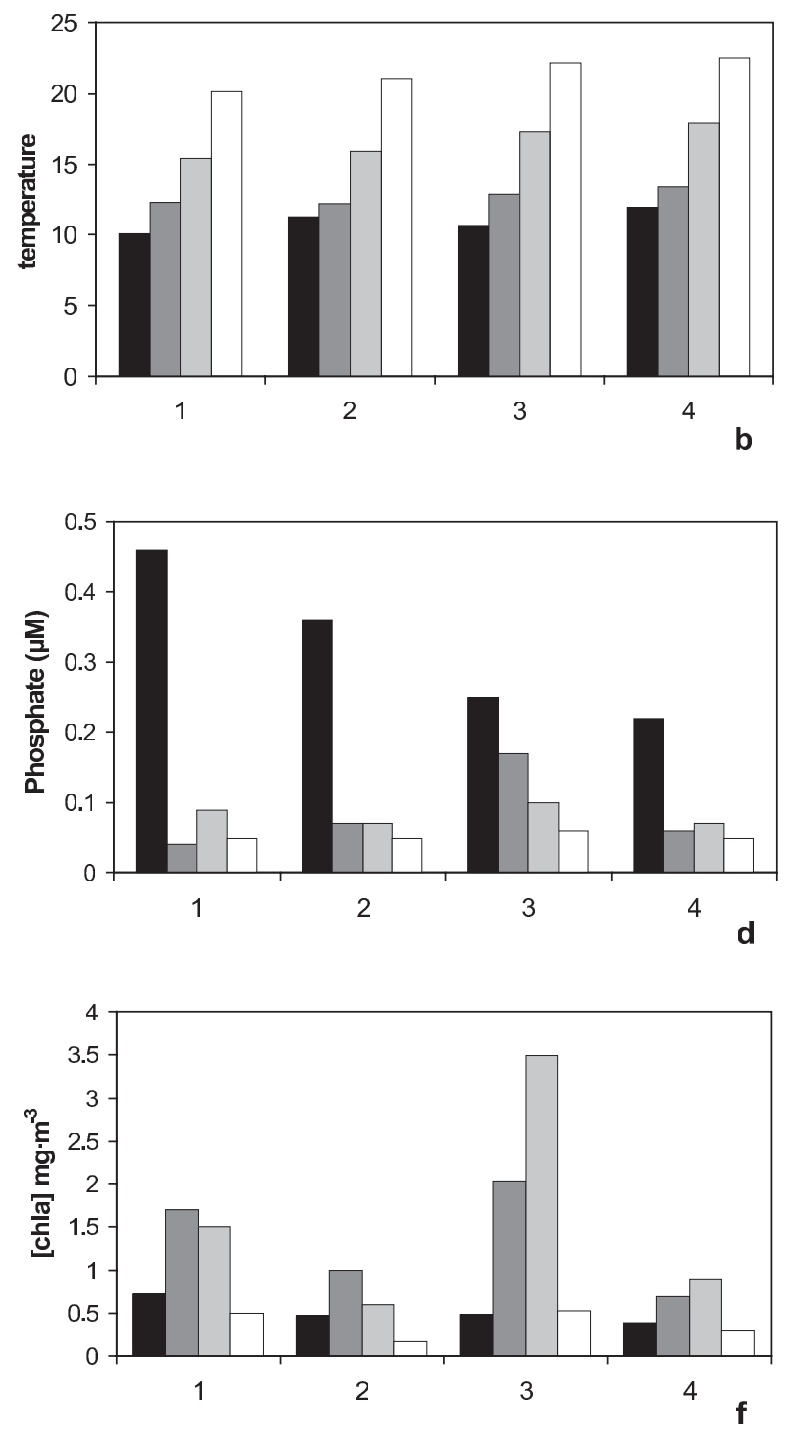

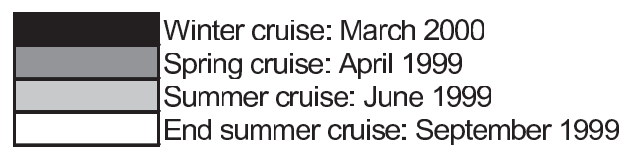

FIG. 4. - Mean surface values for a) salinity, b) temperature, c) nitrate concentrations, d) phosphate concentrations, e) silicate concentrations and f) chlorophyll a concentrations for each areas defined in Figure 1 and for each cruise. 
TABLE 1. - Minimum and maximum values of nutrient concentrations for each area defined in Figure 1 and for each cruise.

\begin{tabular}{|c|c|c|c|c|c|c|c|c|c|c|c|c|}
\hline & \multicolumn{3}{|c|}{ March 2000} & \multicolumn{3}{|c|}{ April 1999} & \multicolumn{3}{|c|}{ June 1999} & \multicolumn{3}{|c|}{ September 1999} \\
\hline & DIN & DIP & DSi & DIN & DIP & DSi & DIN & DIP & DSi & DIN & DIP & DSi \\
\hline \multirow[t]{2}{*}{1} & 11.2 & 0.26 & 5.15 & 3.14 & 0.02 & 0.35 & 0.08 & 0.05 & 0.26 & 0.04 & 0.04 & 0.45 \\
\hline & 32.1 & 1.06 & 38.2 & 21.8 & 0.05 & 0.98 & 3.31 & 0.24 & 2.5 & 0.72 & 0.08 & 9.32 \\
\hline \multirow[t]{2}{*}{2} & 3.9 & 0.27 & 1.81 & 0.09 & 0.03 & 0.3 & 0.03 & 0.03 & 0.53 & 0.04 & 0.03 & 0.37 \\
\hline & 14.8 & 0.68 & 7.0 & 4.19 & 0.32 & 0.81 & 0.67 & 0.12 & 1.31 & 0.21 & 0.1 & 1.05 \\
\hline \multirow[t]{2}{*}{3} & 3.01 & 0.1 & 1.54 & 0.13 & 0.04 & 0.03 & 0.06 & 0.06 & 0.26 & 0.05 & 0.03 & 0.9 \\
\hline & 32.5 & 0.48 & 18.1 & 16.2 & 0.52 & 8.97 & 5.95 & 0.15 & 3.55 & 0.28 & 0.1 & 2.48 \\
\hline \multirow[t]{2}{*}{4} & 2.32 & 0.12 & 1.08 & 0.04 & 0.03 & 0.28 & 0.04 & 0.04 & 0.26 & 0.05 & 0.02 & 0.61 \\
\hline & 4.48 & 0.32 & 2.16 & 1.04 & 0.18 & 0.74 & 3.96 & 0.12 & 1.71 & 0.13 & 0.09 & 1.68 \\
\hline
\end{tabular}

low salinity river plumes are absent and the halocline has become a much less significant feature of the water column. The thermal stratification is well established with a strong vertical gradient in the vicinity of $30 \mathrm{~m}$ depth.

Two main structures of the French continental shelf were not observed during our cruises, i.e. the seasonal thermal front of the western Brittany coast and the local upwelling along the southern continental shelf. The thermal front is related to interactions between the topography and the tidal currents.

\section{Chemical and biological environment}

The shelf has been divided into four parts according to the EW and NS gradients (Fig. 1). Parts 1 and 3 represent coastal areas that are mainly influenced by the Loire and Gironde inputs respectively. Areas 2 and 4 correspond mainly to north and south offshore waters of the shelf. The temperature, salinity, nutrient and chlorophyll $a$ concentrations were estimated for each area and are presented according to their surface seasonal variability (Fig. 4 and Table 1).

In winter, nutrient concentrations in waters located in front of the Loire River (area 1) are twice as high as those under the influence of the Gironde (area 3) (Fig. 4 c-e). These high values of inshore nutrient concentrations clearly reflect the effects of river discharges along the coast. The distribution of chlorophyll $a$ is close to that of nutrients, with a higher value in front of the Loire River (Fig. 4f). The chlorophyll $a$ average is about $0.5 \mathrm{mg} \mathrm{m}^{-3}$. Chlorophyll $a$ concentrations are weak and located in the surface layer (Fig. 5a), and are dominated by diatoms (Lampert, 2001).

During spring, overall nutrient concentrations are on the decline (Fig. 4 c-e). In April 1999, the surface nitrate concentrations decrease from coastal to offshore water values. Silicate and phosphate concentrations follow a similar trend with a considerable decrease in front of the Loire estuary (area 1) (Fig.
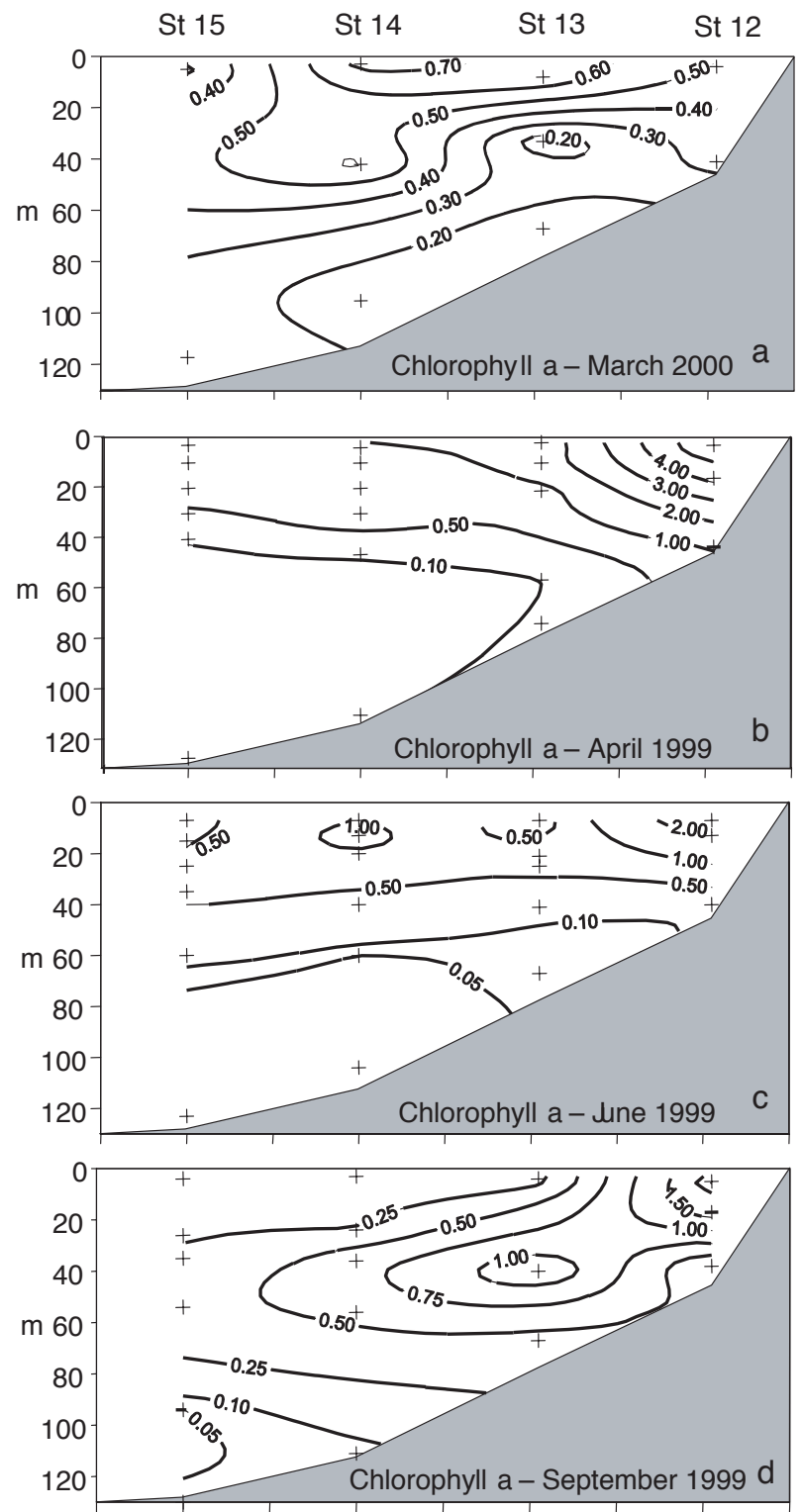

FIG. 5. - Vertical transects (see Fig. 1) of chlorophyll $a\left(\mathrm{mg} \mathrm{m}^{-3}\right)$; a) winter cruise: March 2000; b) spring cruise 1: April 1999; c) spring cruise 2: June 1999; d) end of summer cruise: September 1999.

4d, e). For the two Loire areas (1 and 2), the mean phosphate concentration is lower than $0.1 \mu \mathrm{M}$. 
TABLE 2. - Correlation values between each variables and the three main factors.

\begin{tabular}{lccc}
\hline & Factor: 1 & Factor: 2 & Factor: 3 \\
\hline salinity & -0.56 & 0.11 & -0.09 \\
DIN & 0.43 & 0.52 & 0.25 \\
DIP & 0.29 & -0.62 & -0.39 \\
DIS & 0.25 & -0.20 & 0.73 \\
chl $a$ & 0.52 & -0.17 & -0.17 \\
temperature & -0.30 & -0.52 & 0.47 \\
\hline
\end{tabular}

From winter to spring, the algal biomass shows a two to four fold increase. The surface concentrations range from lower offshore values to higher shelf values (Fig. 4), the maximum value reaches $6 \mathrm{mg} \mathrm{m}^{-3}$ in front of the Gironde estuary. In April, all the biomass is located in the mixed-surface layer (Fig. 5b). The vertical chlorophyll $a$ distribution follows the nitrate repartition closely (results of the transect in front of the Loire estuary, results not shown). The higher nitrate concentrations are confined to the inner shelf, between the coast and the $40 \mathrm{~m}$ isobath.

In summer (June), there is a slight nitrate maximum in the coastal strip (areas 1 and 3), coinciding with low salinity water, which may be due to the influence of land runoff (Fig. 4c). Surface phosphate and silicate concentrations are clearly depleted and remain weak during the rest of the year, except in area 3 where phosphate concentrations decrease more progressively.

The overall chlorophyll $a$ range is $0.3 \mathrm{mg} \mathrm{m}^{-3}$ to 6.5 $\mathrm{mg} \mathrm{m}^{-3}$. In offshore waters, the algal biomass is concentrated in the thermocline (at about $40 \mathrm{~m}$ deep) and it spreads into the surface layer near the coast (between 5 and $20 \mathrm{~m}$ deep) (Fig. 5c). The high surface
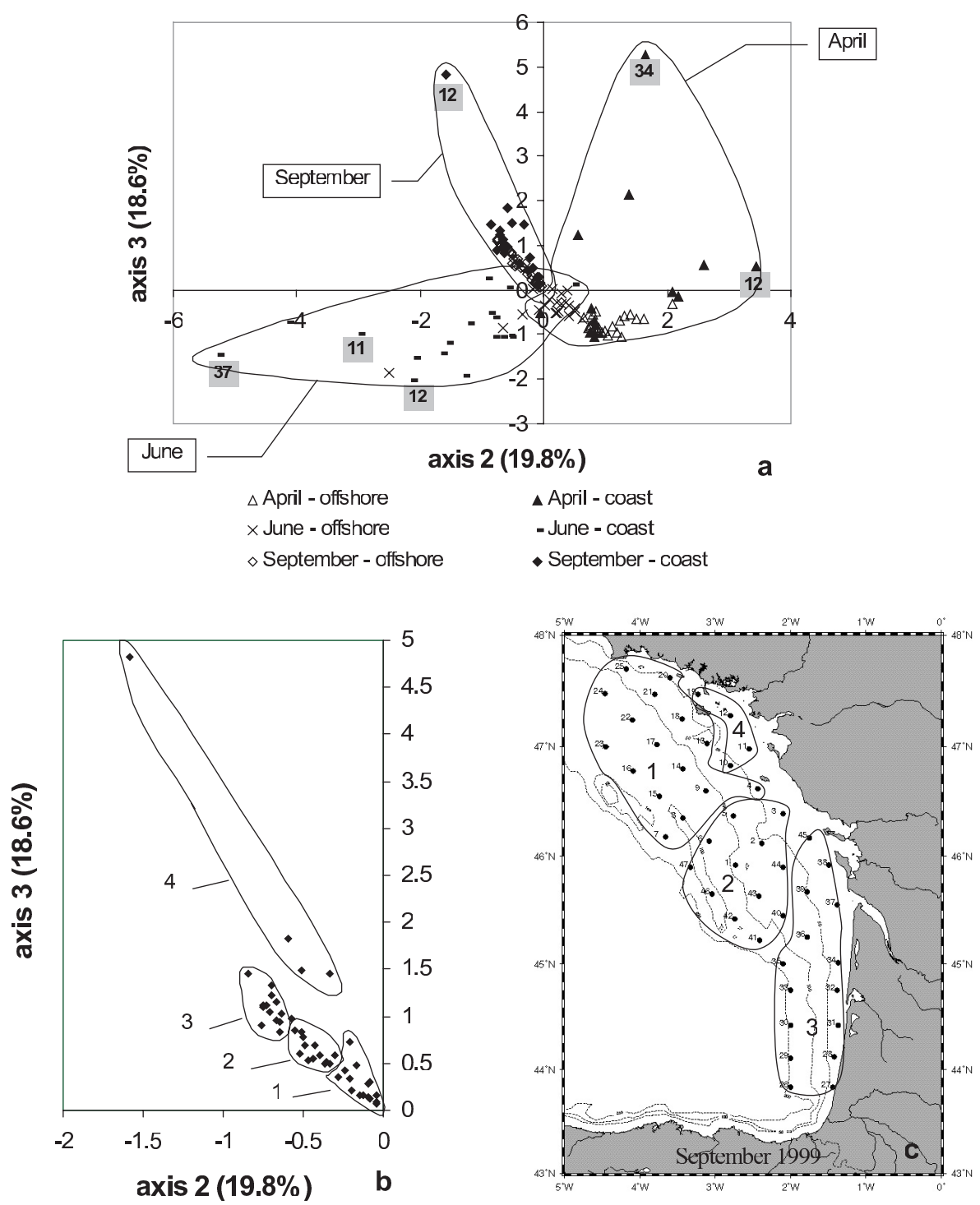

FIG. 6. - Results of the PCA analysis, a) plot of the observations in the plane of axes 2 and 3, b) zoom of the previous figure on September observations, c) locations of the stations of each cluster identified in the previous figure. 
concentrations of chlorophyll $a$ have a greater extent in front of the Gironde estuary than in front of the Loire estuary. The most significant percentages of dinoflagellate biomass (15\% in front of the Loire estuary and 37\% in front of the Gironde estuary) are to be found during this summer period (Lampert, 2001).

In September, the nitrate average is ten times weaker than during the April cruise. In the late summer, the phytoplankton growth has depleted nitrate and phosphate stock. Only surface silicate concentrations increase slightly in the two coastal areas (1 and 3) (Fig. 4e)

In the late summer, chlorophyll $a$ concentrations significantly decreased, with small peaks in front of both the Loire and Gironde estuaries (Fig. 4f). The vertical profile shows the characteristic chlorophyll $a$ maximum associated with the nutricline (Fig. 5d) and the thermal stratification.

The ACP analysis indicates that three axes are enough to explain $79.2 \%$ of the total variance. The first axis is strongly inversely correlated to salinity and is highly correlated to DIN and chlorophyll concentrations (Table 2). This axis represents $40.8 \%$ of the total variance and shows the influence of the coastal gradient due to freshwater inputs. The second axis, which retains $19.8 \%$ of the total variance, is inversely correlated to temperature and DIP, and is correlated to DIN (Table 2). The third axis is highly correlated to silicic acid with a correlation coefficient of 0.73. In the second display (axis 2 and axis 3) (Fig. 6a), the three cruises are always distinct. The September stations show a great distribution along the third axis (Figs. $6 \mathrm{~b}$ and $6 \mathrm{c}$ ), following the horizontal gradient of temperature and silicic acid concentration distributions, which are slightly greater in the south part.

\section{Nutrient uptake and N:P:S ratios}

Despite the natural variability found in nature, Aminot et al. (1998) studied N:P and N:Si uptake ratios in the French coastal zone of the Bay of Seine, enriched by freshwater inputs. They have found that $\mathrm{N}: \mathrm{P}$ uptake ratios were close to the traditional Redfield values. Similar measures were made by the same authors in front of the Loire estuary and along the South Brittany coast during April 2002, where they found a $\mathrm{N}: \mathrm{P}$ uptake ratio close to 18 and a $\mathrm{N}: \mathrm{Si}$ ratio close to 0.7 (pers. comm., not yet published). This N:Si ratio corresponds well with the composition of diatoms (Brzezinski, 1985), which are the primary contributors of the Bay of Biscay phyto-
Waters located north from $46^{\text {th }}$ parallel in March 2000 Areas 1 and 2
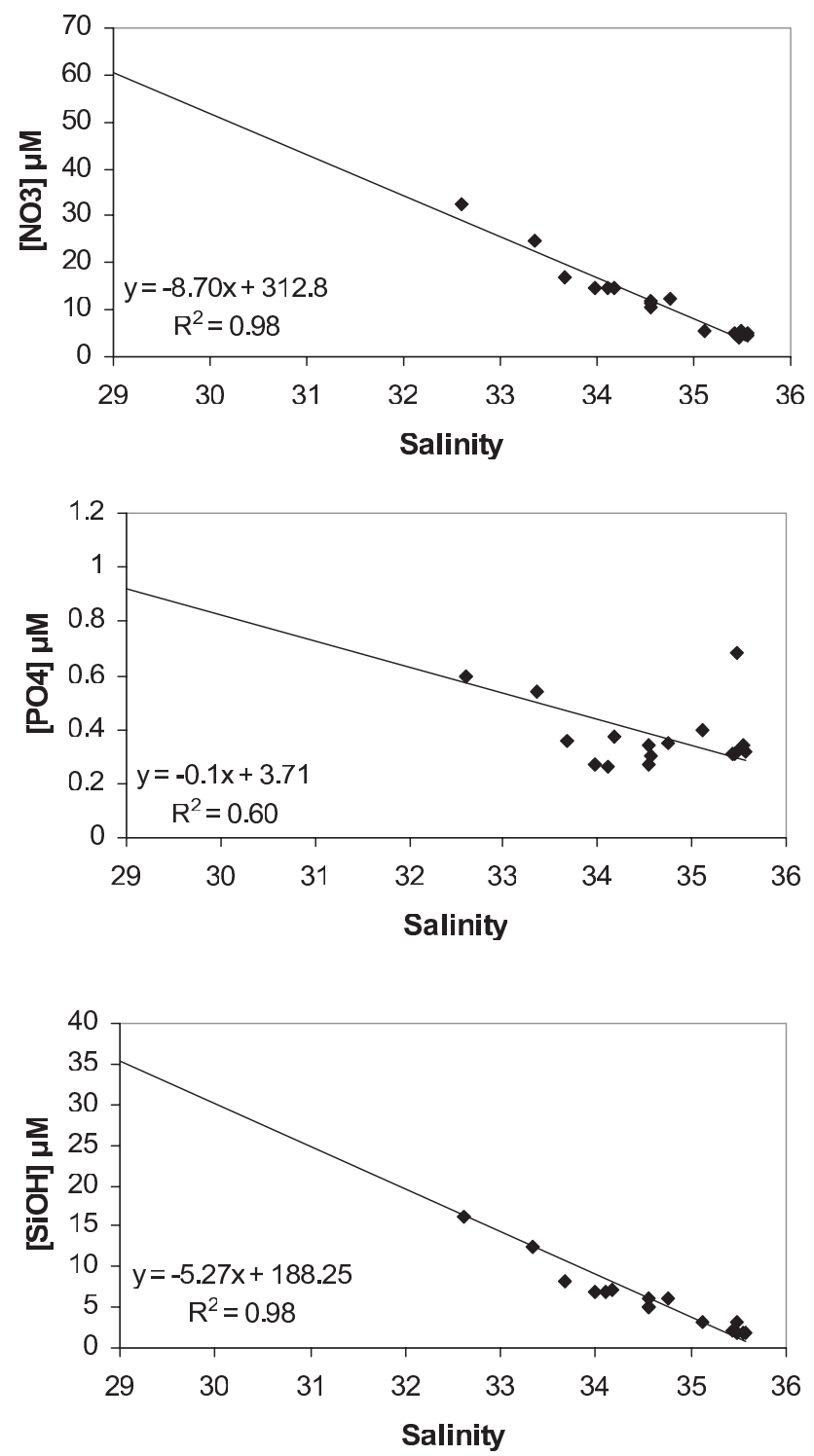

FIG. 7. - Nutrient versus salinity relationships for waters located north of the 46th parallel, mainly influenced by the Loire plume. a) nitrate $(\mu \mathrm{M}), \mathrm{b})$ phosphate $(\mu \mathrm{M})$, c) silicate $(\mu \mathrm{M})$.

plankton production. As a consequence, we assume that the conceptual model of $\mathrm{Si}: \mathrm{N}: \mathrm{P}$ of 16:16:1 could be a reasonable reference for this study. These classical values give estimates of the relative nutrient requirements of diatoms (Fisher et al., 1992).

In March 2000, nutrient dilution is linear in the salinity range of 30 to 35.5 in front of the Loire River (Fig. 7). Therefore, in the assumption of a conservative mixing, the expected values of nitrate, phosphate and silicate for a salinity equal to 0 would be respectively about $300 \mu \mathrm{M}, 3.5 \mu \mathrm{M}$ and $190 \mu \mathrm{M}$ in front of the Loire inlet. Because agricultural prac- 
Waters located south from $46^{\text {th }}$ parallel in March 2000

Areas 3 and 4
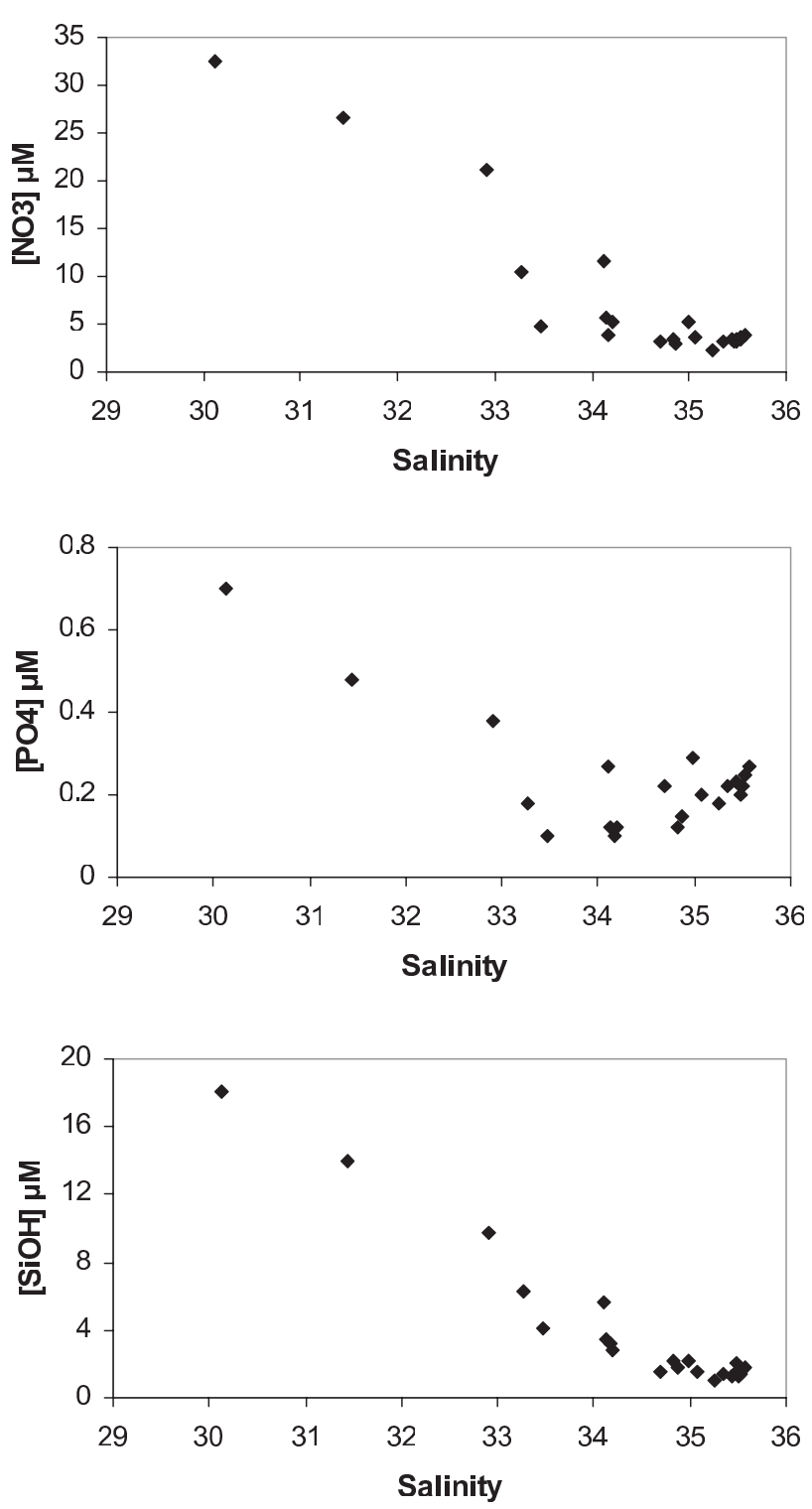

FIG. 8. - Nutrient versus salinity relationships for waters located south of the 46th parallel, mainly influenced by the Gironde plume. a) nitrate $(\mu \mathrm{M})$, b) phosphate $(\mu \mathrm{M})$, c) silicate $(\mu \mathrm{M})$.

tice and urban sewage are the main sources of nutrient influx, the most influential factor in the nutrient loads is the variability of annual rainfall. The Loire winter flows in 1999 and 2000 have similar mean values of 1720 and $1735 \mathrm{~m}^{3} \mathrm{~s}^{-1}$. During these two winter periods, nutrient inputs are also supposed to be equivalent, which enables the dilution line established with the winter measurements of March 2000 to be taken as a dilution reference for the year 1999. In the southern part (areas 3 and 4), the plot of nutrient concentrations in function of salinity (Fig. 8) already reveals a nutrient depletion above 33 during
UPTAKES (N, P et Si)

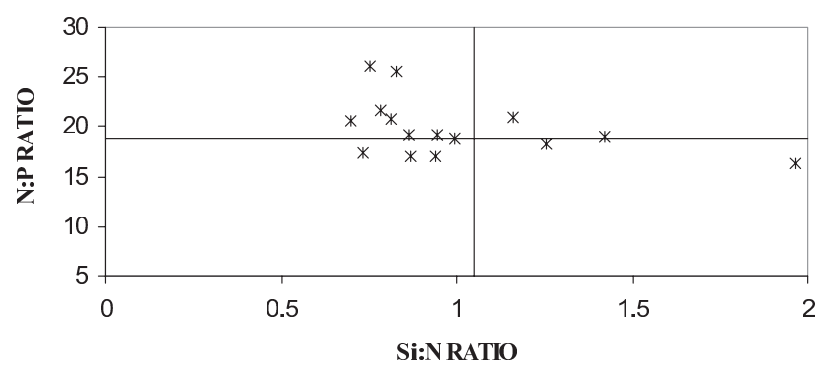

FIG. 9. - Graph of Si:N:P uptake ratio in April 1999.

March 2000. No relationship is clearly detected between nutrient and salinity distributions. As a result, studying these theoretical expected values is limited to the two north areas.

The nutrient uptake by phytoplankton causes negative deviations between values predicted by the theoretical dilution and in-situ measurements. Thus, we can evaluate the theoretical nutrient uptakes in the north areas 1 and 2 during the spring bloom of April 1999. The ratio comparison (ratios of DIN consumption to DIP consumption and to DSi consumption) enables the theoretical N:P:Si needs to be estimated. Figure 9 represents the repartition of these estimated nutrient uptake ratios in order to evaluate the simultaneous nutrient deficiency. The N:P uptake ratios range from 16.3 to 21.6 (Fig. 9). The mean ratio between nitrate and phosphate deficits is estimated at 18.8 , which is similar to the usual Redfield value (Redfield et al., 1963). In the same way, Si:N ratios range from 0.7 to 1.9 , with a mean value of 1.05 . This value corresponds to the range observed by Morin (1984) for temperate waters, the range of 0.5 to 1 observed by Le Corre and Treguer (1975) for the Bay of Biscay and the typical mean value equal to 1 found by Brzezinski (1985).

As the estimation of the N:P:Si needs is close to the classical ratio values and to the previous measurements of Aminot and Morin, we assume that the nutrient depletion observed is linked to the spring phytoplankton blooms.

In the following pages, we explore the potential nutrient limitation for phytoplankton growth using the conceptual model of Si:N:P of 16:16:1.

In April, N:P ratios over 16 (Redfield and Richards, 1963) extend not only in front of the Gironde estuary but also in front of the Loire system (Fig. 10a). A potential P-limitation in the coastal area is displayed in early spring. Only the stations located along a south offshore strip seem not to be 


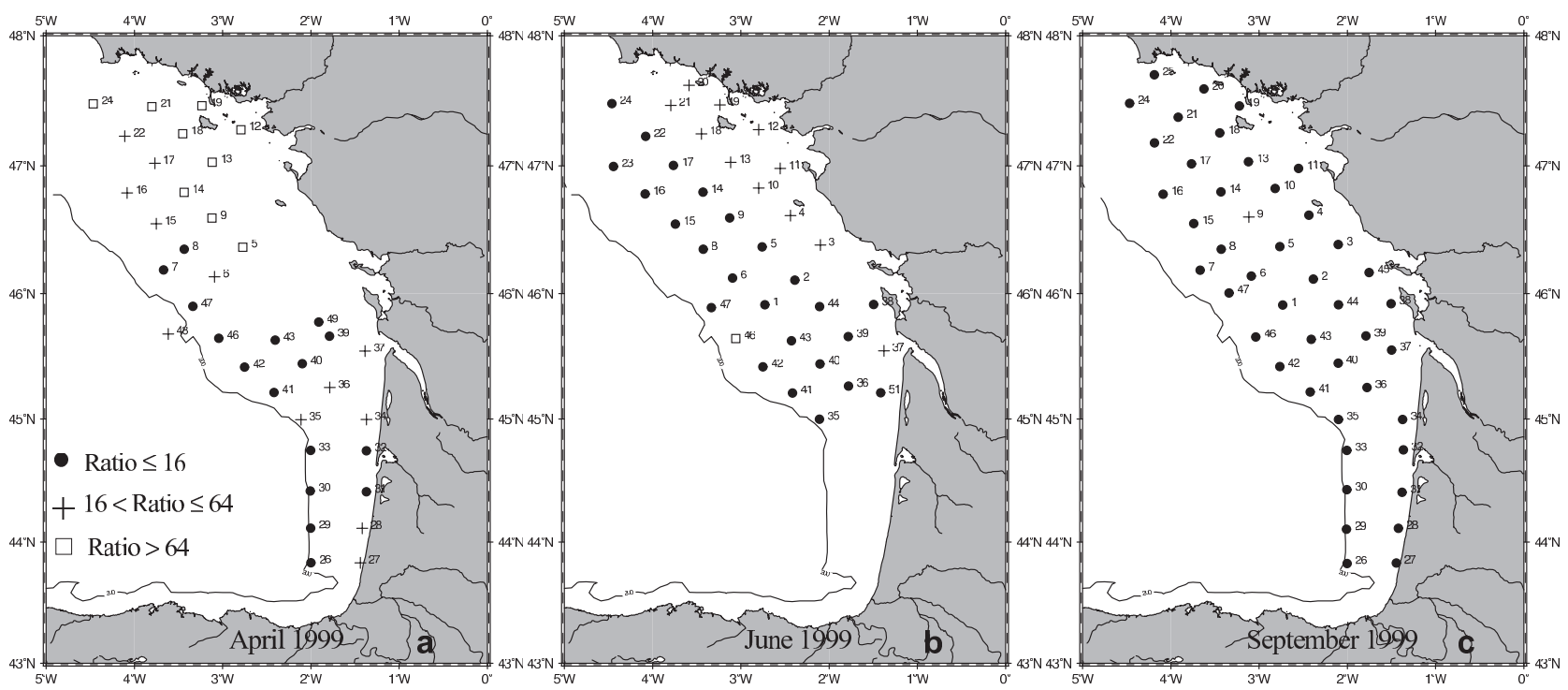

FIG. 10. - N:P surface ratios a) Bio-Modycot 99.1 (April 1999), b) Bio-Modycot 99.2 (June 1999), c) Bio-Modycot 99.3 (September 1999 ).

limited by phosphate. The high N:P ratios found in river plumes in April (Fig. 10a) are due to the large excess of nitrate freshwater inputs compared to those of phosphate. This nitrogen excess is much more pronounced in the Loire plume than in the Gironde plume.

In June (Fig. 10b), the extension of the imbalance between DIP and DIN decreases and it disappears in September (Fig. 10c). N:P ratios reach a maximum during the spring flood, showing a potential P-limitation of coastal stations, and fall down to a minimum during the weak flood period in late summer. During the summer period, the nutrient concentrations decrease to very low values, with nitrate and phosphate concentrations that are more balanced with regard to the potential phytoplankton demand.

Among potentially P-limited stations (Fig. 10a), stations with $\mathrm{Si}: \mathrm{P}$ ratios $<16$ are mainly limited by silicate. These stations are found in the northern part in offshore waters, beyond the $50 \mathrm{~m}$ isobath and in the southern offshore strip (Fig. 11a). Thus in April, offshore waters seem to have a limitation in silicate. Only stations sampled in the Gironde plume seem not to be limited in silicate. Unfortunately, the bad weather did not enable us to confirm this result in front of the Loire estuary. In June, the number of potentially Si-limited stations, with regard to phosphate concentrations, is always large and extends to coastal stations (Fig. 11b). But as the silicate coastal concentrations increase during the summer (Fig.

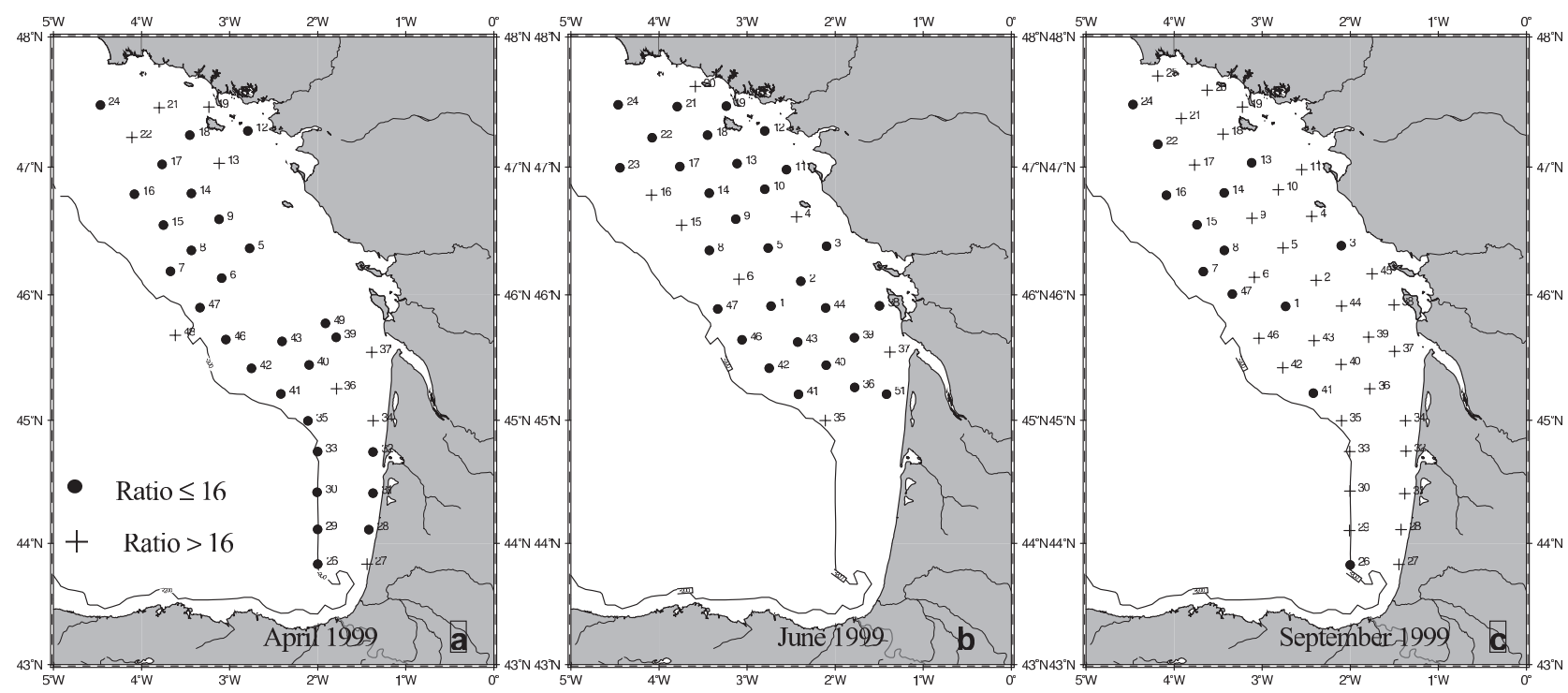

FIG. 11. - Si:P surface ratios a) Bio-Modycot 99.1 (April 1999), b) Bio-Modycot 99.2 (June 1999), c) Bio-Modycot 99.3 (September 1999 ). 


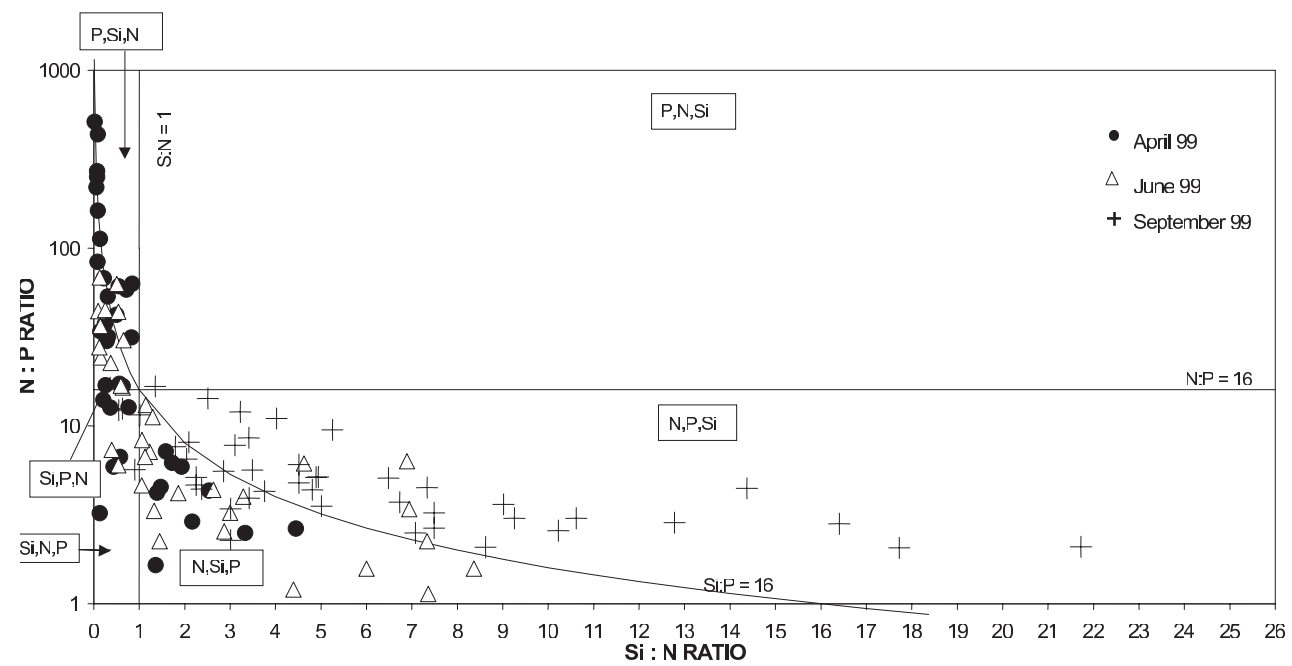

FIG. 12. - Synthetic graph of Si:N:P molar ratios from April to September 1999. Each area is delimited by ratios and illustrates a potential limiting order of priority.

$4 \mathrm{e})$, there is no potential silicate limitation in September.

A synthetic graph of Si:N:P molar ratios (Fig. 12) compares these ratios with typical values for composition of phytoplankton. This graph refers to $\mathrm{Si}: \mathrm{N}: \mathrm{P}$ ratios of $16: 16: 1$, according to Redfield (1963) and Brzezinski (1985). The Si:N=1, N:P=16 and $\mathrm{Si}: \mathrm{P}=16$ lines delimit six areas. Each of them is characterised by the potentially limiting nutrients in order of priority. The three cruises of the year 1999 are plotted. This method, used by Dortch and Whitledge (1992) and Del Amo et al. (1997), illustrates the annual evolution of the potential nutrient limitation. In April (Fig. 12), phosphate and silicate are the common potentially limiting nutrients, except for the stations along the south-offshore strip. In June, the P, Si limitation order of priority is gradually replaced by a $\mathrm{Si}, \mathrm{P}$ and $\mathrm{Si}, \mathrm{N}$ limitation order of priority. This synthetic graph clearly illustrates the shift towards the nitrate limitation during the summer time.

\section{DISCUSSION}

In winter, nutrient concentrations are high and therefore nutrient limitation is not likely to occur. But during the spring bloom, the phytoplankton uptake induces a decrease in phosphate and silicate concentrations to low values with residual ratios clearly different from the standards. $\mathrm{N}$ limited events only occur during the summer. The three major events that stand out in this study are the late $\mathrm{N}$ limitation (1), compared to the early $\mathrm{P}$ limitation, which emphasises the ability to sustain the $\mathrm{N}$ uptake even if $\mathrm{P}$ is potentially limiting (2), and the noticeable increase in silicate concentrations during the summer (3). The discussion deals with the presumed aspects of $\mathrm{Si}$ and $\mathrm{P}$ biogeochemistry which could explain whether $\mathrm{Si}$ or $\mathrm{P}$ spring limitation allows the phytoplankton development and nitrate uptake to be sustained during the year.

Phosphate concentrations measured on the French Atlantic continental shelf are low compared to the means observed in the North Atlantic. Indeed, Conkright et al. (2000) have found winter concentrations of $0.56 \mu \mathrm{M}(+/-0.24)$ and summer concentrations reaching $0.23 \mu \mathrm{M}(+/-0.10)$. The weak concentrations reported in the Bay of Biscay may be explained by phytoplankton consumption which is not limited by nitrogen. A previous study, located in front of the Gironde estuary, has shown that phosphate is the first nutrient to be exhausted in the Gironde plume (Herbland et al., 1998). In this area, works by Labry et al. (2001) support the idea of winter blooms in February and March (earlier than the spring bloom) as a consequence of a conjunction of favourable climatic conditions and haline stratification. These early blooms, which occur in March, quickly exhaust the euphotic zone of phosphate. Chapelle et al. (1994) have also noted a spring phosphate limitation with their ecological model of the Vilaine bay (located north of the Loire estuary).

Among the three major nutrients, phosphate is probably the most difficult one to assess for phytoplankton growth limitation due to its fast biological and geochemical turnover. As phosphate is early limiting, the ability to sustain the primary produc- 
tion and nitrogen removal would reflect a relatively high regeneration rate of phosphate. Phosphate may be regenerated by hydrolytic release, by a microbial loop or sediment release. These three ways have been investigated with the help of other studies located in the same area.

Herbland et al. (1998) also demonstrated that in spring, the Gironde plume system is a 'maintenance' or 'regeneration' system (as defined by Platt et al., 1992). In such a system, new production is highly reduced and active regeneration processes can be observed. These regeneration processes are characterised by: (1) a decreasing size for algae (i.e. $<5 \mu \mathrm{m})$ and grazing mainly realised by microzooplankton; (2) a rapid degradation of the small zooplankton fecal pellets; (3) high bacterial activities; (4) low sedimentation rates. Labry et al. (2002) estimated that about $50 \%$ of the primary production is due to small cells $(<3 \mu \mathrm{m})$ in spring. They also reported significant phosphatase activity. Exocellular alkaline phosphatase is important for algae and bacteria which use dissolved inorganic phosphorus (McKelvie et al., 1995). Its activity is increased when inorganic phosphorus is low or undetectable (Solarzano, 1978). This maintenance system, which supports active phosphate regeneration processes, is characterised by a large proportion of small autotrophic cells. The analysis by Chemotaxonomy (study of pigments as biomarkers of phytoplankton populations) performed in a further study (Lampert, 2001) with this cruise data set, confirmed a decrease in the phytoplankton size class for spring and summer situations. In spring (April 1999), algal group biomass already shows a change in the proportion of diatom between the northern and southern part: in area 1, 63\% of the phytoplankton community is dominated by diatoms while in area 3 , only $48 \%$ of the community are diatoms and $45 \%$ are small cells (Prymnesiophytes and green algae) (Lampert, 2001). During the summer cruise, the value of picoplanktonic algae exceeds $50 \%$ of the total algal biomass. Thus the shift from haline to thermal stratification is accompanied by a change in the phytoplankton community in which the share of diatoms falls below $20 \%$ and the phytoplankton community is dominated by Cyanophytes (Lampert, 2001).

The capacity of marine systems to retain phosphorus in sediment and to remineralise it annually has implications for the temporal evolution of $\mathrm{N}: \mathrm{P}: \mathrm{Si}$ ratios. Moreover according to Caraco et al. (1990) and Aminot et al. (1993), heavy loads of par- ticulate phosphorus (adsorbed, apatite, non-apatite inorganic, organic), expelled from estuaries during floods, may significantly contribute to the enrichment of the coastal zone. Andrieux-Loyer and Aminot (2001) estimated total phosphorus concentrations in the sediment along the French Atlantic coast during February 1991. These concentrations range from 4 to $25 \mathrm{mmol} \mathrm{g}^{-1}$ in the Gironde estuary and from 17 to $44 \mathrm{mmol} \mathrm{g}^{-1}$ in the Loire estuary. During the summer, the difference between water column and sediment enhances desorption of phosphate adsorbed into the surface of minerals. Thus, the sediment may release phosphate when particles are put back into suspension by bottom currents and thus supports the summer algal growth.

Nevertheless, phosphorus can also occur in the sediment in the form of calcium, iron, manganese or aluminium precipitates. Thus, another key to explain phosphate regeneration is the release of phosphate bound to iron, aluminium or manganese oxides during an anoxia (Cloern, 2001). This anoxia generally occurs in the summer because the temperature increase favours the degradation of the organic matter subsequent to the algae dying. This degradation of organic matter favours bacterial processes and thus it increases the oxygen consumption. Nevertheless, oxide forms (Fe/AL-P) seem to be a minority form among the sedimentary phosphorus pools. In the outer estuaries of the Loire and Gironde rivers, they represent respectively $10 \%$ and $15 \%$ of the total sedimentary phosphorus in the Bay of Biscay (Andrieux-Loyer and Aminot, 2001).

Concerning the Si limitation, a similar lack of silicon in April has been reported by Treguer et al. (1979) in the waters of the Irish continental shelf. This lack of silicate, principally in areas 1 and 2, seems to confirm the existence of a previous diatom bloom before the April cruise. This assumption is supported by Morin et al. (1991), who observed a phytoplankton bloom in March in the zone of haline stratification on the Armorican shelf. These first spring blooms do not occur at the same period every year because they are highly dependent on the meteorological conditions. It is the shallow surface mixed layer during a haline stratification which permits early blooms (even in mid-February, if the thickness of the mixed layer is around $20 \mathrm{~m}$ ) (Labry et al., 2001).

The evolution in the N:Si ratios from spring to summer (for June and September) is the feature of silicate replenishment, while nitrate concentrations continue to decrease. This is probably due to redis- 
solution processes because river flows during the summer period are too weak to generate detectable surface enrichment. This regeneration can occur during the summer, probably with the silicic acid regeneration via frustule dissolution from the end of spring diatom blooms. This assumption is consistent with the description made by Ragueneau et al. (1994) of the biogeochemical cycle of silicon for the Bay of Brest ecosystem (France). They have split it into three stages, (1) the silicate input from rivers which sustains the major spring diatom bloom, (2) the recycling of silicate within the water column, which sustains the second bloom of smaller diatoms and (3) the recycling at the sediment water interface which contributes to silicate production during summer. Nevertheless, the frustule dissolution from the spring bloom most probably does not take place in surface waters because the dissolution of silicon is not a rapid process in comparison with the diatom sedimentation. The silicate concentrations probably increase on the bottom along the coast and are transported to the surface with mixing processes or upwelling events. These upwelling processes frequently occur during summer with north wind events (Lazure and Jegou, 1995; Koutsikopoulos and Le Cann, 1996).

The Principal Component Analysis shows that in September, the main characteristic of the horizontal gradient is a NS component, which affects not only temperature but also silicate concentrations. Therefore, the dissolution seems to be more efficient in the southern part and in front of the Loire estuary. Two main assumptions can explain this fact: (1) The temperature increase favours the dissolution of silicic detritic matter; Kamatani (1982) showed that the regeneration of particulate biogenic silica is strongly temperature dependent. (2) The kind of sediment plays a role in the dissolution process; a silty sand sea floor contains a large fraction of silicate minerals.

This seasonal shift of nutrient limitation has already been described for other coastal systems. These features seem to be a regular feature of $\mathrm{N}$ enriched ecosystems. The same result is reported in the Chesapeake Bay (Conley and Malone, 1992; D'Elia et al., 1992; Fisher et al., 1998). In spring, D'Elia et al. (1992) observed a potential P-limitation with rapid turnover rates for phosphate, while in summertime, the ratios fall well below the level at which potential N-limitation can occur. As in the Chesapeake Bay and the Bay of Biscay, phosphate is limiting in the Northern Adriatic coastal ecosystems
(Justic et al., 1995). Nevertheless, owing to the increase in phosphate discharge over the last 20 years, the Northern Adriatic ecosystem is subject to an oscillation between phosphorus and nitrogen limitations (Thornton et al., 1999). In the North Sea, Woodward and Owens (1990) pointed out that North Sea waters are phosphate depleted in spring, especially in waters under the influence of river inputs. More recently, Guillaud et al. (2000) showed the limiting role of phosphate in the Seine plume during spring due to the decrease in phosphate in freshwater inputs over the last two decades.

In the same way, several studies have highlighted the hypothesis of Si-limitation for diatom growth in nitrate-rich coastal waters (Schelske and Stoermer, 1971; Schelske and Stoermer, 1972; Officer and Ryther, 1980; Smayda, 1989; Smayda and White, 1990; Maestrini and Graneli, 1991; Conley and Malone, 1992; Egge and Aksnes, 1992; Rabalais et al., 1996; Rahm et al., 1996). It is believed to cause a shift in species composition which may result in harmful phytoplankton blooms (Schelske and Stoermer, 1972; Smayda, 1989; Smayda and White, 1990; Maestrini and Graneli, 1991; Egge and Aksnes, 1992).

In the Chesapeake Bay, Si-limitation occurs similarly at the end of the spring and causes the collapse of the spring bloom. In the Mississippi estuary, nitrate has been reckoned as the most limiting nutrient; but in the recent past, river input of nitrate has increased while silicate input has been strongly reduced (Dortch and Whitledge, 1992). In this bay, the productivity of diatoms has reached the upper level set due to silicate availability and thus any further increase in $\mathrm{N}$ and $\mathrm{P}$ loads could lead to a dominance of non-siliceous taxa (Justic , 1995). Similar conclusions have been found previously by Le Pape et al. (1995) in the Bay of Brest and by Guillaud and Menesguen (1998) in the Bay of Seine.

\section{CONCLUSION}

This study describes the temporal and spatial variability of chemical features of the French Atlantic shelf, and complements the geographical extent of the previous studies located along the south Brittany coast, in the bay of Vilaine and in the Gironde estuary. Previous measurements along the French coast have shown that the classical molar ratios (Redfield et al., 1983, Brzezinski, 1985) could be a reasonable reference to the composition of 
diatoms. As a consequence, we have studied the potential nutrient limitation in reference to these ratios. Of course, examining residual nutrient ratios alone does not give definitive conclusions. The real limitation depends on the species composition associated with their specific kinetic curves, and the regeneration rates of each nutrient.

Freshwater inputs contribute in great part to the nutrient enrichment, particularly in nitrogen. The most important aspect of freshwater inputs is a large excess of nitrate with regard to phosphate and silicate concentrations, which introduces a strong imbalance in nutrient ratios. The coastal gradient in nitrogen, due to the presence of less saline waters, is distinguishable until June while phosphate and silicate concentrations are already depleted in April. The winter nitrate supply persists throughout spring and nitrate concentrations are depleted in late summer. From spring to summer, we can observe a shift from a potential phosphate and silicate limitation to a potential nitrate limitation.

From spring to summer, the temporal and spatial variations of silicate reflect: freshwater runoffs, rapid loss by diatom uptake and sinking, and benthic regeneration. Although low silicate concentrations do not rule out limitation by other nutrients, Si:P ratios lower than 16 suggest that in spring, silicate is more limiting than phosphate in the northern offshore waters.

This study provides a description of the nutrient distribution at a precisely defined moment and does not allow us to estimate the dynamics of nutrient and phytoplankton growth. We can only presume that, according to the dilution graph and the low DIP concentrations, during the April cruise we were at the end of the microphytoplankton growth. However what we have observed at a particular time does not inform us about regeneration processes and our assumptions on the potential nutrient limitation could be affected by these dynamics. Especially for small cells, these measurements are insufficient to arrive at definite conclusions about the nutrient limitation.

\section{ACKNOWLEDGEMENTS}

We wish to thank the captain, officers, crew and hydrographs of $\mathrm{BH} 2$ Laperouse for their support at sea during the cruise, as well as N. Lebreton, X. Lenhardt and A.S. Cussatlegras for kind help in water sampling.

\section{REFERENCES}

Aminot, A., J.F. Guillaud and F. Andrieux. - 1993. Phosphorus speciation and inputs to the eastern bay of Seine. Oceanol. Acta, 16 (5-6): 617-623.

Aminot, A., J.F. Guillaud, F. Andrieux-Loyer, R. Kerouel and P. Cann. - 1998. Apports de nutriments et développement phytoplanctonique en baie de Seine (France). Oceanol. Acta, 21 (6): 923-938.

Andrieux-Loyer, F. and A. Aminot. - 2001. Phosphorus forms related to sediment grain size and geochemical characteristics in French coastal areas. Estuar. Coastal. Shelf Sci., 52: 617629.

Belin, C., J. Berthome and P. Lassus. - 1989. Toxic dinoflagellates and discoloured waters along the French littoral: Evolution and trends between 1975 and 1988. Hydroécol. Appl., 1 (2): 3-17.

Biggs, D.C. and L.L. Sanchez. - 1997. Nutrient enhanced primary productivity of the Texas-Louisiana continental shelf. J. Mar. Syst., 11 (3-4): 237-247.

Boucher, J. - 1985. Caractéristiques physiques et biologiques du domaine pélagique. In: L. Laubier and C. Monniot (eds), Peuplements profonds du Golfe de Gascogne, Campagne BIO$G A S$, pp. 25-70. Ifremer, Brest, France.

Brzezinski, M. - 1985. The Si:C:N ratio of marine diatoms: Interspecific variability and the effect of some environmental variables. J. Phycol., 21 (3): 347-357.

Caraco, N.J., J. Cole and G.E. Likens, G. - 1990. A comparison of phosphorus immobilisation in sediments of freshwater and coastal marine systems. Biogeochemistry, 9: 277-290.

Chapelle, A., P. Lazure and A. Ménesguen. - 1994. Modelling eutrophication events in a coastal ecosystem. Sensitivity analysis. Estuar. Coast. Shelf Sci., 39 (6): 529-548.

Conkright, M., W. Gregg and S. Levitus. - 2000. Seasonal cycle of phosphate in the open ocean. Deep Sea Res., 47 (2): 159-175.

Conley, D. and T. Malone. - 1992. Annual cycle of dissolved silicate in Chesapeake Bay: Implications for the production and fate of phytoplankton biomass. Mar. Ecol. Prog. Ser., 81 (2): 121-128.

Cloern, J. E. - 2001. Our evolving conceptual model of the coastal eutrophication problem. Mar. Ecol.Prog. Ser., 210: 223-253.

De Jonge, V.N., W. Boynton, C.F. D'Elia, R. Elmgren and B.W Welsh. - 1994. Responses to developments in eutrophication in four different North Atlantic estuarine systems. In: K.R. Dyer and R.J. Orth (eds), Changes in Fluxes in estuaries: implications from Science to Management, pp.179-196. Proceedings, ECSA22/ERF Symposium, International Symposium Series, Olsen \& Olsen, Fredensborg, Denmark.

Del Amo, Y., B. Queguiner, P. Treguer, H. Breton and L. Lampert. - 1997. Impacts of high-nitrate freshwater inputs on macrotidal ecosystems. 2. Specific role of the silicic acid pump in the yearround dominance of diatoms in the Bay of Brest (France). Mar. Ecol. Prog. Ser., 161: 225-237.

D'Elia, C.F., L.W. Jr. Harding, M. Leffler and G.B. Mackiernan. 1993. The role and control of nutrients in Chesapeake Bay. Water Sci. Technol., 26: 2635-2644.

Delmas, D., A. Herbland and S. Maestrini. - 1992. Environmental conditions which lead to increase in cell density of the toxic dinoflagellates Dinophysis spp. in nutrient-rich and nutrientpoor waters of the French Atlantic coast. Mar. Ecol. Prog. Ser., 89 (1): 53-61.

Dortch, Q. and T. Whitledge. - 1992. Does nitrogen or silicon limit phytoplankton production in the Mississippi River plume and nearby regions? Cont. Shelf. Res., 12 (11): 1293-1309.

Egge, J. and D. Aksnes. - 1992. Silicate as regulating nutrient in phytoplankton competition. Mar. Ecol. Prog. Ser., 83 ( 281289): $2-3$.

Fisher, T., L.W. Jr. Harding, D. Stanley and L. Ward. - 1988 Phytoplankton, nutrients, and turbidity in the Chesapeake, Delaware, and Hudson estuaries. Estuar. Coast. Shelf Sci., 27 (1): 61-93.

Fisher, T., E. Peele, J. Ammerman and L. Harding. - 1992. Nutrient limitation of phytoplankton in Chesapeake Bay. Mar. Ecol. Prog. Ser. 82 (1): 51-63.

Guillaud, J.F. and A. Menesguen. - 1998. Modelling over twenty years (1976-1995) of the phytoplanktonic production in the Bay of Seine. Oceanol. Acta, 21 (6): 887-906.

Guillaud, J.F., F. Andrieux and A. Menesguen. - 2000. 
Biogeochemical modelling in the Bay of Seine (France): an improvement by introducing phosphorus in nutrient cycles. $J$. Mar. Syst., 25 (3-4): 369-386.

Harding, L.W., Jr. and E. Perry. - 1997. Long-term increase of phytoplankton biomass in Chesapeake Bay, 1950-1994. Mar. Ecol. Prog. Ser., 157: 39-52.

Herbland, A., D. Delmas, B. Sautour and F. Artigas. - 1998. Phytoplankton spring bloom of the Gironde plume waters in the Bay of Biscay: early phosphorus limitation and food-web consequences. Oceanol. Acta, 21 (2): 279-291.

Hermida, J., P. Lazure, J.M. Froidefond, A.M. Jegou and P. Castaing. - 1998. Seaward dispersion of Gironde estuarine waters on to Aquitain continental shelf from hydrological satellite and numeric data. Oceanol. Acta, 21 (2): 209-221.

Joint, I. and A. Pomroy. - 1993. Phytoplankton biomass and production in the southern North Sea. Mar. Ecol. Prog. Ser., 99 (12): $169-182$

Justic, D., N.N. Rabalais and R. Turner. - 1995. Stoichiometric nutrient balance and origin of coastal eutrophication. Mar. Pollut. Bull., 30 (1), 41-46.

Kamatani, A. - 1982. Dissolution rates of silica from diatoms decomposing at various temperatures. Mar. Biol., 68 (1): 91-96.

Koutsikopoulos, C. and B. Le Cann. - 1996. Physical processes and hydrological structures related to the Bay of Biscay anchovy. Sci. Mar. Barc., 60 (2): 9-19.

Labry, C., A. Herbland, D. Delmas, P. Laborde, P. Lazure, J.M. Froidefond, A.M. Jegou and B. Sautour. - 2001. Initiation of winter phytoplankton blooms within the Gironde plume waters in the Bay of Biscay. Mar. Ecol. Prog. Ser., 212: 117-130.

Labry, C., A. Herbland, and D. Delmas. - 2002. The role of phosphorus on planktonic production of the Gironde plume waters in the Bay of Biscay. J. Plank. Res., 24: 97-117.

Lampert, L. - 2001. Dynamique saisonnière et variabilité pigmentaire des populations phytoplanctoniques dans l'Atlantique nord (Golfe de Gascogne). Ph. D. thesis, Univ. Bretagne Occidentale, spécialité : Océanographie Biologique.

Lancelot, C., G. Billen, A. Sournia, T. Weisse, F. Colijn, M. Veldhuis, A. Davies and P. Wassman. - 1987. Phaeocystis blooms and nutrient enrichment in the continental coastal zones of the North Sea. Ambio., 16 (1): 38-46.

Lazure, P. and A.M. Jegou. - 1998. 3D modelling of seasonal evolution of Loire and Gironde plumes on Biscay Bay continenta shelf. Oceanol. Acta, 21 (2): 165-177.

Le Pape, O., Y. Del Amo, P. Cann, A. Menesguen, A. Aminot, B. Queguiner and P. Treguer. - 1995. Response of the Brest bay towards the increase of nutrients imputs. Ing. Eau Agric. Territ., special issue: 103-110.

Legovic, T. and D. Justic. - 1997. When do phytoplankton blooms cause the most intense hypoxia in the northern Adriatic Sea? In: J. Castel (eds), Long term changes in marine ecosystems, pp.91-99. Authiers Villars, Paris, France.

Loyer S., P. Lazure, P. Gentien and A. Menesguen. - 2001. Modelling of Gymnodinium mikimotoï blooms along the French atlantic coast: geographical and vertical distributions. Hydroécol. Appl., 13 (1): 57-76.

Mackey, M.D., D.J. Mackey, H.W. Higgins and S.W. Wright. 1996. CHEMTAX - a program for estimating class abundances from chemical markers: application to HPLC measurements of phytoplankton. Mar. Ecol. Prog. Ser. 144 : 265-283.

Maestrini, S. and E. Graneli. - 1991. Environmental conditions and ecophysiological mechanisms which led to the 1988 Chrysochromulina polylepis bloom: An hypothesis. Oceanol. Acta, 14 (4): 397-413.

Maggi, P., A. Mastouri, P. Lassus, L. Soulard, Y. Cadiou and C. Le Paul. - 1986. Suivi des facteurs climatiques susceptibles de jouer un rôle dans les eaux colorées, en baie de Vilaine, durant l'année 1985. Rapport interne, Ifremer, Nantes, DERO-8603-MR.

Malej, A., P. Mezetic, V. Malacic, S. Terzic and M. Ahel. - 1995. Phytoplankton reponses to freshwater inputs in a small semienclosed gulf (Gulf of Trieste, Adriactic Sea). Mar. Ecol. Prog. Ser., 120: 111-121.

Marchetti, R., A. Provini, G. Gaggino. - 1988. Eutrophication of inland and coastal waters in Italy. In: C. Maltoni (eds), Living in a chemical world: occupational and environmental significance of industrial carcinogen, pp.950-958.

Maurice, L. - 1993. La qualités des eaux dans l'estuaire de la Gironde : synthèse. Contribution au livre blanc de la Gironde. Rapport interne, Ifremer, DEL/93.17.
McKelvie, I., B. Hart, T. Cardwell and R. Cattrall. - 1995. Use of immobilized 3-phytase and flow injection for the determination of phosphorus species in natural waters. Anal. Chim. Acta, 316 (3): 277-289.

Morin, P., P. Le Corre, Y. Le Marty and S. L'Helguen. - 1991. Spring evolution of nutrients and phytoplankton on the Armorican shelf (North-West European shelf). Oceanol. Acta, 14 (3): 263-279.

Officer, C. and J. Ryther. - 1980. The possible importance of silicon in marine eutrophication. Mar. Ecol. Prog. Ser., 3 (1): 83-91.

Peperzak, L., G.J. Snoeijer, R. Dijkema, W.W.C. Gieskes, J. Joordens, J.C.H. Peeters, C. Schol, E.G. Vrieling and W. Zevenboom. - 1996. Development of a Dinophysis acuminata bloom in the river Rhine plume (North Sea). In: T. Yasumoto, Y. Oshima and Y. Fukuyo (eds). Harmful and Toxic Algal Blooms, pp.273-276. Unesco, Paris.

Pingree, R. and B. Le Cann. - 1989. Celtic and Armorican slope and shelf residual currents. Prog. Oceanogr., 23 (4): 303-338.

Platt, T., P. Juahari and Sathyendranath. - 1992. The importance and measurement of new production. In: P.G. Falskowski and A.D. Woodhead (eds), Primary Productivity and Biogeochemical Cycles in the Sea, pp. 273-284. Plenum Press, New York.

Puillat, I., P. Lazure, P. and A.M. Jegou. - 2004. Hydrological variability on the bay of Biscay French continental shelf during the 1990's. Cont. Shelf Res., 24 : 1143-1163.

Rabalais, N.N., R.E. Turner, D. Justic, Q. Dortch, W.J. Jr. Wiseman, W and B.K. Sen Gupta. - 1996. Nutrient changes in the Mississippi River and system responses on the adjacent continental shelf. Estuaries, 19 (2B): 386-407.

Radach, G. - 1991. Ecosystem functioning in the German Bight under continental nutrient inputs by rivers, Couplings Between Watersheds And Coastal Waters. Fifth International Congress of Ecology (INTECOL), Yokahama, Japan, pp.477-496.

Radach, G., J. Berg and E. Hagmeier. - 1990. Long-term changes of the annual cycles of meteorological, hydrographic nutrient and phytoplankton time series at Helgoland and at LV Elbe 1 in the German Bight. Cont. Shelf. Res., 10 (4): 305-328.

Ragueneau, O., E. De Blas Varela, P. Treguer, B. Queguiner and Y. Del Amo. - 1994. Phytoplankton dynamics in relation to the biogeochemical cycle of silicon in a coastal ecosystem of western Europe. Mar. Ecol. Prog. Ser., 106 (1-2): 157-172.

Rahm, L., P. Sanden, F. Wulff, P. Stalnacke and D. Conley. - 1996. Time series analysis of nutrient inputs to the Baltic Sea and changing DSi:DIN ratios, Mar. Ecol. Prog. Ser., 130 (1-3): 221-228.

Redfield, A.C., B.H. Ketchum and F.A. Richards. - 1963. The influence of organisms on the composition of seawater. In: M.N. Hill (eds), The sea vol.2. The composition of seawater, pp.26-77. Wiley \& Sons, New York.

Reid, P., C. Lancelot, W. Gieskes, E. Hagmeier and G. Weichart. 1990. Phytoplankton of the North Sea and its dynamics: A review. Neth. J. Sea. Res., 26 (2-4): 295-331.

Sauriau, P.G., J.F. Guillaud and B. Thouvenin. - 1996. Estuaire de la Loire. Qualité des eaux. Rapport de synthèse de l'APEEL (Association pour la protection de l'environnement de la Loire), 1984-1994.

Schelske, C.L. and E.F. Stoermer. - 1971. Eutrophication, silica depletion and predicted changes in algal quality in Lake Michigan. Can. J. Fish. Aquat. Sci., 48: 1529-1538.

Schelske, C.L. and E.F. Stoermer. - 1972. Phosphorus, silica and eutrophication in Lake Michigan. In: G.E. Likens (eds), Nutrients and eutrophication, Special Symposia vol.1, pp.157171. American Society for Limnology and Oceanography, Allen Press, Lawrence, Kansas.

Smayda, T.J. and A. White. - 1990. Has there been a global expansion of algal blooms. If so, is there a connection with human activities? In: E. Graneli, B. Sundstroem, L. Edler and D.M. Anderson (eds), Toxic Marine Phytoplankton, pp.516-517. Elsevier.

Smayda, T. - 1989. Primary production and the global epidemic of phytoplankton blooms in the sea: a linkage ? In: E.M. Cosper, V.M. Bricelj and E.J. Carpenter (eds), Novel phytoplankton blooms, pp.449-483. Springer-Verlag, New York.

Solarzano, L. - 1978. Soluble fractions of phosphorus compounds and alkaline phosphatase activity in loch Creran and loch Ative, Scotland. J. Exp. Mar. Biol. Ecol.. 34: 227-232. 
Thornton, D., D. Santillo and B. Thake. - 1999. Prediction of Sporadic Mucilaginous Algal Blooms in the Northern Adriatic Sea. Mar. Poll. Bull., 38 (10): 891-898.

Treguer, P., Le Corre, P. - 1975. Manuel d'analyse des sels nutritifs dans l'eau de mer, Université de Bretagne Occidentale, Brest, France.

Treguer, P., P. Le Corre and J.R. Grall. - 1979. The seasonal variations of nutrients in the upper waters of the Bay of Biscay region and their relation to phytoplankton growth. Deep-Sea Res., 26A: 1121-1152.

Turner, R.E. and N.N. Rabalais. - 1991. Changes in Mississippi River water quality this century - implications for coastal food webs. BioScience, 41: 140-147.

Van Der Veer, H., W. Van Raaphorst and M. Bergman. - 1989. Eutrophication of the Dutch Wadden Sea: External nutrient loadings of the Marsdiep and Vliestroom basin. Helgol. Meeresunters, 43 (3-4): 501-515.

Vidussi, F. - 1998. Variabilité spatiale et temporrelle des marqueurs pigmentaires des communautés autotrophes en Méditerrannée : implications biogéochimiques. $\mathrm{Ph} \mathrm{D}$. thesis Univ. Pierre et Marie Curie (Paris VI).

Vincent, A. - 1973. Les variations de la situation thermique dans le Golfe de Gascogne en 1969 et 1979. Revue des Travaux de l'Institut des Pêches maritime, 33(1): 79-96.

Woodward, E. and N. Owens. - 1990. Nutrient depletion studies in offshore North Sea areas. Neth. J. Sea Res., 25 (1-2): 57-63.

Wright, S., S. Jeffrey, R. Mantoura, C. Llewellyn, T. Bjoernland, D. Repeta and N. Welschmeyer. - 1991. Improved HPLC method for the analysis of chlorophylls and carotenoids from marine phytoplankton. Mar. Ecol. Prog. Ser., 77 (2-3): 183-196.

Yin, K., P.J. Harrison, R.H. Goldblatt and R.J. Beamish. - 1996. Spring bloom in the central Strait of Georgia: interactions of river discharge, winds and grazing. Mar. Ecol. Progr. Ser., 138: 255-263.

Scient. ed.: M. Estrada 